\title{
"PROAKTIF TEACHERS" TRAINING TO INCREASE EMOTIONAL REGULATION OF TEACHERS IN VOCATIONAL SCHOOLS
}

\author{
Istiqomah Yungsiana*, Wisjnu Martani \\ *Correspondent Author
}

Istiqomah Yungsiana

Universitas Gadjah Mada

Bulaksumur, Caturtunggal, Kec. Depok,

Kabupaten Sleman, Daerah Istimewa

Yogyakarta

Indonesia

Email: yungsiana@gmail.com

Wisjnu Martani

Universitas Gadjah Mada

Bulaksumur, Caturtunggal, Kec. Depok,

Kabupaten Sleman, Daerah Istimewa

Yogyakarta

Indonesia

Email: wisjnu_m@ugm.ac.id

Page

73-80

\begin{abstract}
Emotion regulation is an important aspect of teachers a teacher's everyday life. However, facts show that some teachers fail to properly regulate their emotions. Accordingly, an intervention is needed to enhance teachers' emotional regulation. "PROAKTIF Teachers" is a training module developed to increase teachers' emotional regulation. The "PROAKTIF Teachers" training was structured based on a "PROAKTIF" Guidance and Counseling Model. This research aimed to find out the effect of "PROAKTIF Teachers" training on vocational School teachers' emotional regulation. The research method was a quasi-experiment using the untreated control group design with dependent pretest and posttest samples. Twenty-six vocational school teachers participated in this study. They were assigned to experimental and control groups. The participants were recruited using the purposive sampling technique. The research instruments were the emotional regulation scale, "PROAKTIF Teachers" module, and the manipulation check. Data analysis used mixed ANOVA. The result of the research showed that "PROAKTIF Teachers" training did not have a significant effect in increasing the emotional regulation of teachers in Vocational schools. The result of the present study could be used as a reference to develop a training model to help vocational school teachers to improve their emotion regulation skills by considering several aspects found in the present study including duration, model, approach, theoretical basis, focus, and psychological values of the training.

Keywords: proactive teacher, emotional regulation, vocational school
\end{abstract}

\begin{abstract}
INTRODUCTION
Everyone has emotional experiences, including teachers. Teachers may experience a range of emotional experiences throughout their careers (Cowie, 2011). These emotional experiences happen because they possess various relationships with colleagues, students, parents, administrators, and other
\end{abstract}

individuals related to their professional life (Cowie, 2011). Teachers often have their emotions triggered because of students' behavior. Disruptive student behaviors could drain teachers' energy, perception, attribution, and assessment (Asrar-ul-Haq, Anwar, \& Hassan, 2017). Mahvar, Farahani, \& Aryankhesal (2018) added that disruptive 
student behaviors could cause unnecessary stress for teachers. Therefore, it is important for teachers to have an emotional regulation skill (Talbot, \& Mercer, 2018; Laible, Carlo, Panfile, Eye, Jessica., \& Parker, 2010; Ariyani, \& Nissa, 2016).

Emotional regulation has an important effect on the learning process in the classroom (Taxer, \& Gross, (2018); Karaben, \& Kustanti, 2020; Khaerunnisa, Hakim, \& Erliana, 2019; Wulan, \& Sari, 2015). Teachers who could regulate their emotions will show more positive emotions and less negative emotions (Jiang, Vauras, Volet, \& Yili, 2015). Teachers with proper emotional regulation skill could encourage students' discipline (Talbot, \& Mercer, 2018). Lombas, Jiménez, Arguís-Rey, Hernández-Paniello, Valdivia-Salas, \& Martín-Albo (2019) added that emotional regulation could reduce conflicts in the classroom, create respectful communication, good problem-solving skills, students' interest in work, and the presence of support as well as the ability to respond to different student needs. Furthermore, teachers who could regulate their emotions can give quality teaching, improvement in education, a good relationship with students, help students to understand the learning materials, and could increase social interactions with students (Rusmaladewi \& Indah, 2018; Cross \& Hong, 2012). Akbari, Samar, Kiany, \& Tahernia (2017) added that emotional regulation could help teachers to achieve the intended learning goals.

An ideal teacher, according to Hosotani and Matsumura (2011), is someone who could express their emotions well and act in a calm manner. Meanwhile, In reality, teachers are often faced with less ideal situations (Ariyani \& Nizza, 2016). This often leads teachers to act in ways like shouting, hitting, angry, labeling, among others. Those behaviors are the manifestations of the teachers' inability to regulate their emotions (Brackett, Palomera, Kaja, Reyes, \& Salovey, 2010).

The image of teachers who lack emotional regulation is in contrast with the role and task of teachers. Such actions violate the Indonesian Teachers' Code of Ethics, Article 2 in particular about the responsibilities of teachers toward students (Ariyani \& Nissa, 2016). Moreover, based on the document Permendiknas no.16 2007 in appendix $A$ in detail states that teachers are considered professional if they are qualified in four competencies, namely: pedagogy, personality, social and professional. Teachers' inability to regulate their emotions fall in the personality competence.

Personality competence is pivotal for a teacher. A teacher's good personality will influence the students' interest in learning (Alimin, 2015). The students may enjoy the learning process when teachers present as a fun individuals. A fun environment also reinforces the learning process (Alimin, 2015). The achievement of the learning goal and process depends on the teachers' competence (Purwanti, 2013). Therefore, teachers' competence improvement is necessary, and as Kristoto, Zakso, and Rivaie (2015) suggest, training could be conducted to enhance teachers' personality competence

"PROACTIVE Teachers" is a training module developed based on the teachers' required competence. "PROAKTIF Teachers" training module is a modification from The Psychological Skills of "PROAKTIF" Guidance and Counselling Model by Atamimi (2011). The Psychological Skills of the "PROAKTIF" Guidance and Counselling Model was developed based on the characteristic of a fully functioning person. A research result from Proctor, Tweed, and Morris (2016) showed that a fully functioning person possesses high life satisfaction. This is shown by the increase in positive thoughts and feelings, low level of anxiety, and ability to shift to intrinsic values. Fully functioning individuals try to develop their potential by giving opportunities to become positive, active, creative, constructive, advanced, developed, willing to go through the process so they could actualize themselves (Atamimi, 2015).

The approach used in the "PROAKTIF Teachers" training module was experiential 
learning. Experiential learning consists of experiencing, reflecting, thinking, and acting. Experiencing could be enhanced by using simulations. Simulations are implemented to provide participants with real-life experience. Reflecting is enhanced through observations of other participants and situations during the training. Thinking is enhanced by the process of debriefing. In the debrief process, participants are asked to conclude what they have learned from the simulations. Acting is achieved in the debrief when participants were asked to discuss the real-world applications of what they have learned during the training.

The aim of this research was to find out the effectiveness of "PROAKTIF Teachers" training in increasing vocational school teachers' emotion regulation. "PROAKTIF Teachers" training module is a modification from The Psychological Skills of "PROAKTIF" Guidance and Counselling Model by Atamimi (2011). The Psychological Skills of "PROAKTIF" Guidance and Counselling Model was developed based on the characteristic of a fully functioning person. The result of the study was expected to be used as a reference in developing training models to help vocational school teachers to improve their emotional regulation.

\section{METHODOLOGY}

The research method was a quasiexperiment using the untreated control group design with dependent pretest and posttest samples. The number of research participants was 26 vocational school teachers who were assigned into experimental and control groups. The participants were recruited using the purposive sampling technique. The research instruments were the emotional regulation scale, "PROAKTIF Teachers" module, and the manipulation check. Data analysis used mixed ANOVA.

\section{RESULT AND DISCUSSION}

A normality test was done using ShapiroWilk. Results from the experimental group in the reappraisal strategy showed a z-score of 0.919 with a significance of $0.240(p>0.05)$, while the suppression strategy had a z-score of 0.895 with a significance of 0.113 $(p>0.05)$. That result indicated that the data were distributed normally.

Homogeneity test was done using the homogeneity of variance-covariance matrices with Box's test. The result showed the significance value was $0.654(p>0.001)$. The result showed that the data was homogenous. In other words, there was a correlation between the emotional regulation score before and after treatment was given

Table 1.

Summary of the Hypothesis Testing

\begin{tabular}{|c|c|c|c|c|}
\hline Source & Measure & & $\mathrm{F}$ & Sig. \\
\hline \multirow[t]{2}{*}{$\begin{array}{l}\text { time * } \\
\text { group }\end{array}$} & Reappraisal & $\begin{array}{l}\text { Sphericity } \\
\text { Assumed }\end{array}$ & 2.153 & 0.127 \\
\hline & Suppression & $\begin{array}{l}\text { Sphericity } \\
\text { Assumed }\end{array}$ & 1.650 & 0.203 \\
\hline
\end{tabular}

The result of the hypothesis test with Mixed ANOVA showed an emotional regulation score in the reappraisal strategy of $\mathrm{F}=2.153$ and significance value of 0.127 $(p>0.05)$, while the suppression strategy obtained a score of $F=1.650$ and significance value of $0.203(p>0.05)$. This means there were no interactions between time (pretest, posttest, and follow-up) and group (experimental and control group). Therefore, it can be concluded that the hypothesis proposed in this research was rejected. In other words, the "PROAKTIF Teachers" training could not enhance vocational skill teachers' emotional regulation. This was proven by the absence of a significant difference in emotional regulation scores between the experimental and the control group.

The purpose of this research was to find out the effectiveness of the "PROAKTIF Teachers" training in increasing vocational school teachers' emotional regulation. The result of the research indicated no interactions between time (pretest, posttest, and follow-up) and group (experimental and control group). Nevertheless, based on the results of interviews, participants felt they benefit from participating in the training. This was supported by the result of the participants' reflection recapitulation in each 


\section{6| PSIKOPEDAGOGIA}

JURNAL BIMBINGAN DAN KONSELING

Vol.9, No.2, December 2020

session, showing that, in general, participants obtained the learning goal

There was no interaction between time (pretest, posttest, and follow-up) and group (experimental and control group). It may occur due to the measurement instruments used in this research. The measurement instrument used in the research was the Emotion Regulation Questionnaire (ERQ) Morawetz, Bode, Baudewig, \& Heekeren (2017), which was modified by Purnamaningsih (2015). Purnamaningsih's (2015) modified ERQ is a measurement instrument that was related to emotional regulation in general, as shown in each ERQ item which is related to general emotional regulation and is not specified to a certain situation. At the same time, this research concerns the teachers' emotional regulation while they were at school. This research had shown specific emotional regulation, namely teachers' emotional regulation in a school setting. Therefore, the evaluation of this research is to use instructions and measurement instruments that are designed to specifically measure the emotional regulation of teachers in the school environment.

Experiential learning was applied during the participants' learning process. Participants gained concrete experience through experiencing simulations that were done during the training. The experience was used as learning materials to be identified and interpreted. After that, participants performed reflective observation through skills like listening, paying attention, grouping differences, and applying ideas that could help them find knowledge and share them with other participants. Participants could also perform a review by perceiving and understanding what has been done (Bohon, McKelvey, Rhodes, \& Robnolt, 2017). In this process, participants were facilitated to interpret the experiences they received from the simulation or from previous encounters. Participants could combine experiences with ideas, reflection, and concepts that had been learned from simulations during the training. Participants then gain abstract conceptualization by understanding and interpreting the simulations. The recapitulation result indicated that some participants, in general, obtained the intended learning goal. However, some participants also reported that they did not obtain the learning goal, which influenced the next cycle of the study. Participants who had not gained the learning goal formulated in each session were held back in applying the knowledge in everyday life.

The result of this research contradicts Atamimi (2011), Fitriyani (2014), Sari (2014), and Dalimunthe (2014) is as follows. This difference may be accounted for by the duration of the training, the methods used in conveying the module, and the approach in constructing the module. In Atamimi's (2011) research, the Psychological Skills of "PROAKTIF" Guidance and Counselling Model training was given in 3 days and two nights (30 hours), while in this research, the "PROAKTIF Teachers" training was given for 12 hours 20 minutes in a span of two days. The result of this research is supported by similar research by Atamimi (2015) and Anggawati (2016). Atamimi's (2015) research result showed that self-perception, selfesteem, and work motivation didn't show any signs of improvement after the Psychological Skills of "PROAKTIF" Guidance and Counselling Model training was given for 14 hours in a span of 2 days. In line with it, the research result reported by Anggawati (2016) showed that interactions between teachers and kindergarten students didn't increase after "Inspirative Teachers" training was given for 11 hours and 30 minutes in a span of 3 days. However, Fitriyani's (2014), Sari's (2014), and Dalimunthe's (2014) treatment were able to increase emotional regulation (Fitriyani, 2014), elementary teachers' interpersonal communication (Sari, 2014), and problem-solving skills after given Psychological Skills of "PROAKTIF"-R Guidance and Counselling Model training for 12 hours.

Another cause for the difference in research results was accounted for by the method used to convey the module. In the 
research by Fitriyani (2014), Sari (2014), and Dalimunthe (2014), observational learning was applied, while in the present research and in Atamimi's (2015) and Anggawati (2016), experiential learning method was applied. On the other hand, the research result by Atamimi (2011) showed that perception, self-esteem, pride, work satisfaction, work motivation increased after the Psychological Skills of "PROAKTIF" Guidance and Counselling Model using the experiential learning method was given. Therefore, the difference in the method of conveying the same module could influence the result of the research.

The approach used in constructing the module also resulted in the different results of the research. The approach used in constructing Atamimi's (2011) research module was humanistic (Roger \& Adler) (Anggawati, 2016), while in the research by Fitriyani (2015), Sari (2014), and Dalimunthe (2014) Roger's humanistic and Bandura's behavioristic were applied. Previous studies have shown different approaches to develop the module. Nevertheless, the result of the research showed an increase after the Psychological Skills of "PROAKTIF" Guidance and Counselling Model training. On the other hand, another Atamimi's (2015) study using Roger's and Adler's humanistic approach did not result in any improvement. This is also supported based on the research by Anggawati (2016), which used approaches in constructing the module using Vygotsky's social constructivist approach. No improvement was reported after conducting the "Inspirative Teachers" training related to the interactions of teachers and students in Kindergarten. This research result also supports Atamimi's (2015) and Anggawati (2016), which didn't report any increase in emotional regulation after given "PROAKTIF Teachers" training which used a humanistic approach in constructing a module (Roger).

Based on the explanation above, the researcher concluded that there was an inconsistency in the result of the research after treatment was given, which referred to the same concept, which was "PROAKTIF" Guidance and Counselling Model. Atamimi
(2011) said that the "PROAKTIF" Guidance and Counselling Model was based on the principles of humanistic theories. The principle of the humanistic theories, which the research referred to, is general and based on that principles, it was defined into the eight proactive acronyms. Proactive acronym comprises of meaning and model that could facilitate school counselors to achieve self-actualization to become a professional school counselor. Nevertheless, the research result from Atamimi (2015) suggests that "PROAKTIF" Guidance and Counselling Model training was a combination of theory and practice. The training model where PRO became the end result of the skills shown, AFT as the theoretical foundations, IF became the primary foundations to support the implementation of psychological skills (Atamimi, 2015).

Unclear theoretical basis made the researcher interpret that the concept of "PROAKTIF" Guidance and Counselling Model was made based on the characteristic of the fully-functioning person (Atamimi, 2011). The fully functional person includes the person-centered theory from Carl Roger. Based on research results from Laible, Carlo, Panfile, Eye, and Parker (2010), personcentered theory indirectly correlated with emotional regulation. Person-centered theory serves as a mediator between emotional regulation and social behavior. Therefore, Laible et al. (2010) support the result of this research which didn't indicate any increase in teachers' emotional regulation after given the "PROAKTIF Teachers" training. The reason was that in this research, the "PROAKTIF Teachers" training was expected to directly increase the emotional regulation of teachers in vocational schools. However, the basic theory of the "PROAKTIF Teachers" module, i.e., the person-centered theory, could not directly be linked with emotional regulation but serves as a mediator between emotional regulation and social behavior.

Atamimi (2011) said that PROAKTIF is an acronym, AKT (Affection, Cognition, Behavior) was the theoretical foundation. AKT is the basis of emotional regulation and 


\section{8| PSIKOPEDAGOGIA}

JURNAL BIMBINGAN DAN KONSELING

Vol.9, No.2, December 2020

the component in forming attitude. Based on the result of the research, it was shown that components that shape attitude could affect emotional regulation (Sharpe \& Wallis, 2014; Harmon-Jones, Harmon-Jones, Amodio, \& Gable, 2011). Therefore, the goal that was intended in the building tower session, to reveal multiple intelligence and also get closer with students, is better communicated because, as reported by participants, their experiences in the entire three sessions serve as the basis to determine and direct their response to various situations. As an example, a situation that makes them emotional.

PRO is the final skill shown after the training was given (Atamimi, 2015). The success and failure of the training are best measured using a measurement instrument that relates with Peka (Awareness), Responsif (Responsive), Operasional (Operational). But, the method used to confirm the independent variable has been operated at the intended level. In this research, a knowledge test was conducted. Knowledge test was constructed based on the materials that were presented, namely: Peka (Awareness), Responsif (Responsive), Operasional (Operational, Afeksi (Affection), Kognisi (Cognition), Tingkah laku (Behavior), Ikhlas (Willing), and Fasilitasi (Facilitating). The manipulation check used in this research was not on target because it had not been able to measure the intended goal. Therefore, future research is recommended to use manipulation check by creating an instrument that is related to awareness, responsiveness, and operational.

Teaching experiences are one of the aspects that influences teachers' skills and knowledge. Shawer (2017) found that teachers with teaching experiences for more than seven years had high self-efficacy. In the present study, nine participants had seven or more years of experience (experimental group and control group). That number is higher than participants who teach less than seven years. Teaching experiences also influence the result of the measurement from pretest to posttest and follow up on experimental groups. Employees with higher work hours stand a smaller chance to be open to changes. This is supported by Susanti Anggawati (2016), who states that long working hours could shape a habit of learning in class. Thus it is difficult to make changes.

Another threat that influences the result of this research is history. History is when an event happens at the same time as the treatment. The "PROAKTIF Teachers" training was done during the new student's admission period. The majority of the participants were the committee of the event. Participants had duties and responsibilities to obtain new students also attending the training. Therefore, the two events happening at the same time influenced the end result of this research.

It is recommended for future researchers to conduct training for vocational schools to improve their emotional regulation. In conducting such training, several aspects should be taken into consideration, including duration, model, approach, theoretical basis, conditioning of the training. In addition, the training should consider the psychological values.

\section{CONCLUSION}

Based on the result of the research, it can be concluded that the "PROAKTIF Teachers" training could not increase the vocational school teachers' emotional regulation. This is indicated by no significant difference in the emotional regulation score between the experimental and the control group. However, some benefits of the training were reported by participants.

\section{REFERENCES}

Akbari, R., Samar, R. G., Kiany, G. R., \& Tahernia, M. (2017). A qualitative study of EFL teachers' emotion regulation behavior in the classroom. Theory and practice in Language Studies Journal, 7(4), 311321.

Alimin. (2015). Analisis kompetensi kepribadian guru pendidikan agama 
islam smp di Tarakan. Jurnal Kebijakan dan Pengembangan Pendidikan, 3(1).

Anggawati, F.. (2016). Validasi modul "guru inspiratif" untuk meningkatkan interaksi guru dan siswa Taman Kanak-kanak. Tesis (tidak diterbitkan). Yogyakarta: Universitas Gadjah Mada.

Ariyani, M., \& Nissa, S. Z.. (2016). Regulasi emosi pada guru ditinjau dari status pernikahan. Jurnal Penelitian dan Pengukuran Psikologi, 5(2).

Asrar-ul-Haq, M., Anwar, S., \& Hassan, M. (2017). Impact of emotional intelligence on teacher ${ }^{\prime} \mathrm{s}$ performance in higher education institutions of Pakistan. Future Business Journal, 3(2), 87-97.

Atamimi, N. (2011). Keterampilan psikologis model BK "PROAKTIF". Disertasi. Yogyakarta: Universitas Gadjah Mada.

Atamimi, N. (2015). Keterampilan psikologis model "BK PROAKTIF" Untuk Mengembangkan Karakter dan Kepribadian Guru SD yang Humanis. Jurnal Pendidikan Karakter, 5(1).

Atamimi, N. (2015). Keterampilan psikologis model bimbingan konseling proaktif untuk guru Sekolah Dasar. Jurnal Cakrawala Pendidikan, 34(3).

Bohon, L. L., McKelvey, S., Rhodes, J. A., \& Robnolt, V. J. (2017). Training for content teachers of English language learners: Using experiential learning to improve instruction. Teacher Development Journal, 21(5), 609634.

Brackett, M. A., Palomera, R., Kaja, J. M., Reyes, M. R., \& Salovey, P. (2010). Emotion-regulation ability, burnout, and job satisfaction among british secondary-school teachers. Psychology in The Schools Journal, 47(4).

Cowie, N. (2011). Emotions that experienced English as a foreign language (EFL) teachers feel about their students, their colleagues and their work.
Teaching and Teacher Education Journal, 27(1), 29-36.

Cross, D. I., \& Hong, J. Y. (2012). An ecological examination of teachers' emotions in the school context. Teaching and Teacher Education Journal, 28, 957-967.

Dalimunthe, H. L. (2014). Pelatihan keterampilan psikologis model BK "PROAKTIF" untuk meningkatkan kemampuan pemecahan masalah pada guru SD. Tesis (tidak diterbitkan). Yogyakarta: Universitas Gadjah Mada.

Fitriyani, R. (2014). Pelatihan keterampilan psikologis model BK "PROAKTIF"-R untuk meningkatkan regulasi emosi guru SD. Tesis (tidak diterbitkan). Yogyakarta: Universitas Gadjah Mada.

Harmon-Jones, E., Harmon-Jones, C., Amodio, D. M., \& Gable, P. A.. (2011). Attitudes toward emotions. Journal of Personality and Social Psychology, 101(6), 1332-1350.

Hosotani, R., \& Matsumura, K. I. (2011). Emotional experience, expression, and regulation of high-quality japanese elementary school teachers. Teaching and Teacher Education Journal, 27(6), 10391048

Jiang, J., Vauras, M., Volet, S., \& Yili, W. (2015). Teachers' emotions and emotion regulation strategies: selfand students' perceptions. Teaching and Teacher Education Journal, 54, 22-31.

Karaben, G.A., \& Kustanti, E.R. (2020). Hubungan antara regulasi emosi dengan perilaku prososial guru di SLB Negeri Semarang. Jurnal Empati, 9(4).

Khaerunnisa, S.H., Hakim, L., \& Erliana, Y.D. (2019). Regulasi emosi guru pendamping anak berkebutuhan khusus di SDIT Insan Qurani Sumbawa Besar, Jurnal Psimawa, 2(1).

Kristoto, P. E. S., Zakso, A., \& Rivaie, W.. (2015). Pengaruh kompetensi 


\section{0| PSIKOPEDAGOGIA}

JURNAL BIMBINGAN DAN KONSELING

Vol.9, No.2, December 2020

kepribadian guru terhadap keberhasilan siswa dalam belajar sosiologi SMA Kemala Bhayangkari 1. Jurnal Pendidikan dan Pembelajaran, 4(12).

Laible, D., Carlo, G., Panfile, T., Eye, Jessica., \& Parker, J.. (2010). Negative emotionality and emotion regulation: $A$ person-centered approach to predicting socioemotional adjustment in young adolescents. Journal of Research in Personality, 44, 621-629.

Lombas, A. S., Jiménez, T. I., Arguís-Rey, R., Hernández-Paniello, S., ValdiviaSalas, S., \& Martín-Albo, J. (2019). Impact of the happy classrooms programme on psychological wellbeing, school aggression, and classroom climate. Mindfulness Journal, 10(8), 1642-1660.

Mahvar, T., Farahani, M. A., \& Aryankhesal, A. (2018). Conflict management strategies in coping with students' disruptive behaviors in the classroom: Systematized review. Journal of Advances in Medical Education \& Professionalism, 6(3), 102.

Morawetz, C., Bode, S., Baudewig, J., \& Heekeren, H. R. (2017). Effective amygdala-prefrontal connectivity predicts individual differences in successful emotion regulation. Social Cognitive and Affective Neuroscience Journal, 12(4), 569585.

Proctor, C., Tweed, R., \& Morris, D.. (2016). The Rogerian fully functioning person: a positive psychology perspective. Journal of Humanistic Psychology, 56(5), 503-529.

Purnamaningsih, E. H. (2015). Pengaruh psikoedukasi strategi regulasi emosi reappraisal terhadap kualitas hidup orang dengan hipertensi. Disertasi (Tidak diterbitkan). Yogyakarta: Universitas Gadjah Mada.
Purwanti. (2013). Guru dan kompetensi kepribadian. Jurnal Visi IImu Pendidikan, 10(1).

Sari, N. (2014). Keterampilan psikologis model BK"PROAKTIF"-R untuk meningkatkan komunikasi interpersonal guru SD. Tesis (tidak diterbitkan). Yogyakarta: Universitas Gadjah Mada.

Sharpe, E., \& Wallis, D. J. (2014). Attitudes towards emotional expression, emotion regulation and eating psychopathology. Appetite Journal, 83(354).

Shawer, S. F. (2017). Teacher-driven curriculum development at the classroom level: Implications for curriculum, pedagogy and teacher training. Teaching and Teacher Education Journal, 63, 296-313.

Talbot, K., \& Mercer, S. (2018). Exploring university ESL/EFL teachers' emotional well-being and emotional regulation in the United States, Japan and Austria. Chinese Journal of Applied Linguistics, 41(4), 410432.

Taxer, J. L., \& Gross, J. J. (2018). Emotion regulation in teachers: the "why" and "how". Teaching and Teacher Education Journal, 74, 180-189.

Wulan, D.K., \& Sari, N. (2015). Regulasi emosi dan burnout pada guru honorer sekolah dasar swasta menengah ke bawah. Jurnal Penelitian dan Pengukuran Psikologi, 4(2). 